\title{
In vitro antimicrobial activity of betel, Piper betle leaf extract against Vibrio alginolyticus isolated from Asian sea bass, Lates calcarifer
}

\author{
Ahmad Baihaqi Othman ${ }^{1 *}$, Mohd Zamri Saad ${ }^{1,2}$, Nik Haiha Nik Yusof ${ }^{3}$, Siti Zahrah Abdullah ${ }^{4}$ \\ ${ }^{1}$ Faculty of Veterinary Medicine, Universiti Putra Malaysia, 43400 Serdang, Selangor, Malaysia, ${ }^{2}$ Laboratory of Marine Biotechnology, Institute of Bioscience, \\ Universiti Putra Malaysia, 43400 Serdang, Selangor, Malaysia ${ }^{3}$ Marine Aquaculture Breeding Technology Centre, FRI Tg Demong, 22200 Besut, Terengganu, \\ Malaysia, ${ }^{4}$ National Fish Health Research Division (NaFisH), 11960 Batu Maung, Penang, Malaysia.
}

\section{ARTICLE INFO}

\section{Article history:}

Received on: December 31, 2017

Accepted on: February 18, 2018

Available online: May 22, 2018

\section{Key words:}

Piper betle,

Vibrio alginolyticus,

Disc diffusion method,

Minimum inhibitory concentration,

Minimum bactericidal concentration.

\section{ABSTRACT}

Betel plant, Piper betle has excellent potential to be used as an alternative antimicrobial agent to replace the use of commercial antibiotic in aquaculture. The present study evaluates the in vitro antimicrobial activity of betel leaf extract against Vibrio alginolyticus isolated from Asian sea bass, Lates calcarifer. Disc diffusion method was used to evaluate the antimicrobial activity of different concentrations of betel leaf extract and to compare the antimicrobial activity with commercial antibiotics. Broth dilution method was used to determine the minimum inhibitory concentration (MIC) and the minimum bactericidal concentration $(\mathrm{MBC})$ of the extract against $V$. alginolyticus. It was found that $100 \mathrm{mg} / \mathrm{mL}$ of the extract produced significantly $(P<0.05)$ largest inhibition zone $(19 \mathrm{~mm})$ compared to other concentrations. Concentrations between 10 and $80 \mathrm{mg} / \mathrm{mL}$ of the extract produced inhibition zone similar $(P>0.05)$ as the commercial antibiotics. The MIC and MBC for the extract at $100 \mathrm{mg} / \mathrm{mL}$ were $0.2 \mathrm{mg} / \mathrm{mL}$ and $0.39 \mathrm{mg} / \mathrm{mL}$, respectively. The results show that ethanolic crude extract of betel leaves at $100 \mathrm{mg} / \mathrm{mL}$ is a potential alternative to antibiotic against $V$. alginolyticus infection.

\section{INTRODUCTION}

Aquaculture is an important industry as it helps to overcome the rising demand for food fish. Since commercial fishing industry involving wild stock of fish has reached the production limit, aquaculture is an alternative initiative to overcome this problem [1]. Asian sea bass, Lates calcarifer is one of the important fish species that is being cultured in Southeast Asia [2]. It is a euryhaline species with the ability to tolerate a wide range of salinity thus a popular fish for culture [3].

In intensive aquaculture environment, increasing stress factors such as poor water quality and high stocking density expose fish to diseases [4]. Vibriosis is one of the main bacterial diseases that affect cultured marine fish, inflicting high losses, and Vibrio alginolyticus has being identified to be one of the bacteria associated with vibriosis in aquaculture around the world [5,6]. The symptoms are quite similar with other bacterial infections, which include drowsiness, loss of appetite, discoloration, reddened and ulcerative skin, disoriented swimming pattern, exophthalmia, and bloating of the abdomen [7].

The most common treatment against bacterial infections in aquaculture is antibiotic since it is effective against a wide range of bacteria and cost effective. The most frequently used antibiotics in aquaculture are

\footnotetext{
*Corresponding Author

Ahmad Baihaqi Othman,

Universiti Putra Malaysia, Selangor, Malaysia.

Email: baihaqiothman@gmail.com
}

tetracycline, quinolones, and phenols while the route of administration is either oral, injection, or bath [8].

Plants have been known to have various medicinal properties [9]. One of the plants that have been identified to contain antimicrobial compounds is betel plant, Piper betle. Betel plant is a native of Malaysia but is more popular and being used widely in other places such as India [10]. Betel is a vein plant with yellowish-green to bright green, heart-shaped leaves that belong to the family Piperaceae (Pepper family). There are about 100 varieties of betel plants around the world with different chemotypes in each region [11].

Betel leaves contain various compounds such as water, carbohydrates, proteins, fat, minerals, vitamins, tannin, fiber, alkaloid, steroidal compounds, and essential oil [12]. However, the main active compounds that are responsible for the antibacterial effect are the hydroxychavicol, sterol, and tannin $[13,14]$. This study determines the in vitro efficacy of ethanolic betel leaf extract against $V$. alginolyticus isolated from diseased Asia sea bass.

\section{MATERIALS AND METHODS}

One $\mathrm{kg}$ of fresh local betel leaves was collected and thoroughly washed with distilled water. The leaves were air dried for $72 \mathrm{~h}$ and grounded into powder form before $100 \mathrm{~g}$ of the betel leaves powder were immersed into $3 \mathrm{~L}$ of absolute ethanol for $48 \mathrm{~h}$. This was followed by filtration and concentrated using rotary evaporator. 
$V$. alginolyticus was isolated earlier from an outbreak of vibriosis among Asian sea bass in Besut, Terengganu. The isolate was identified as $V$. alginolyticus using the API identification system (Biomerieux) and polymerase chain reaction. It was subcultured onto tryptone soy agar (TSA, Merck, Germany) containing 1.5\% sodium chloride for $24 \mathrm{~h}$ at $30^{\circ} \mathrm{C}$.

Five colonies of $V$. alginolyticus grown on TSA containing $1.5 \%$ sodium chloride were cultured in $250 \mathrm{~mL}$ tryptone soy broth containing $1.5 \%$ sodium chloride for $24 \mathrm{~h}$ at $30^{\circ} \mathrm{C}$ with shaking at $150 \mathrm{rpm}$. Then, $1 \mathrm{~mL}$ of the suspension was collected and serially diluted for 10 times in $9 \mathrm{~mL}$ phosphate-buffered saline (PBS, Merck, Germany) before $0.1 \mathrm{~mL}$ of each serial dilution was plated onto plate count agar containing $1.5 \%$ sodium chloride. The colony-forming unit $/ \mathrm{mL}$ was determined after $24 \mathrm{~h}$ of incubation at $30^{\circ} \mathrm{C}$.

Thirty $\mu$ of $1.25 \mathrm{mg} / \mathrm{mL}, 2.5 \mathrm{mg} / \mathrm{mL}, 5 \mathrm{mg} / \mathrm{mL}, 10 \mathrm{mg} / \mathrm{mL}, 20 \mathrm{mg} / \mathrm{mL}$, $40 \mathrm{mg} / \mathrm{mL}, 80 \mathrm{mg} / \mathrm{mL}$, and $100 \mathrm{mg} / \mathrm{mL}$ dilutions of the extract was dispensed onto $6 \mathrm{~mm}$ antibiotic assay discs, respectively. Absolute ethanol (99.98\%) was used as a control. Each concentration was prepared in triplicate before the discs were allowed to dry at room temperature. Stock culture of $V$. alginolyticus was inoculated into the TSA containing $1.5 \%$ sodium chloride and incubated for $24 \mathrm{~h}$ before being further incubated in Mueller-Hinton broth containing $1.5 \%$ sodium chloride for $24 \mathrm{~h}$. PBS was used to adjust the inoculum to $0.5 \mathrm{McF}$ arland turbidity standard. The bacterial suspension was swapped onto the Mueller-Hinton agar using a sterile cotton swab before the discs with the diluted extract were put onto the agar. The commercial oxytetracycline disc $(30 \mu \mathrm{g})$, oxolinic acid $(2 \mu \mathrm{g})$, and chloramphenicol $(30 \mu \mathrm{g})$ were used for comparison. The agar plates were then incubated for $24 \mathrm{~h}$ at $30^{\circ} \mathrm{C}$. The experiment was carried out in triplicate, and the inhibition zone was measured and recorded. The results were compared with BBL zone interpretative chart to determine the sensitivity of the isolate to the antibiotics.

Betel leaf extract at a concentration of $100 \mathrm{mg} / \mathrm{mL}$ was introduced into Muller-Hilton broth before serially diluted to obtain concentrations of $50 \mathrm{mg} / \mathrm{mL}, 25 \mathrm{mg} / \mathrm{mL}, 12.5 \mathrm{mg} / \mathrm{mL}, 6.25 \mathrm{mg} / \mathrm{mL}, 3.13 \mathrm{mg} / \mathrm{mL}$, $1.56 \mathrm{mg} / \mathrm{mL}, 0.78 \mathrm{mg} / \mathrm{mL}, 0.39 \mathrm{mg} / \mathrm{mL}, 0.20 \mathrm{mg} / \mathrm{mL}$, and $0.09 \mathrm{mg} / \mathrm{mL}$. Then, $1 \mathrm{~mL}$ of bacterial suspension was added into each diluted betel leaf extract. The broth without betel leaf extract was used as control. The mixtures were incubated at $30^{\circ} \mathrm{C}$ for $24 \mathrm{~h}$ before the turbidity was determined. The broth that did not show any turbidity was used as minimum inhibitory concentration (MIC) [15], while the lowest concentration that did not show any bacterial growth was recorded as minimum bactericidal concentration (MBC).

\section{RESULTS}

Crude extract of betel leaves at a concentration of $1.25 \mathrm{mg} / \mathrm{mL}$ produced an inhibition zone of $1 \mathrm{~mm}$ that was significantly $(P<0.05)$ increased to $3 \mathrm{~mm}$ at a concentration of $2.5 \mathrm{mg} / \mathrm{mL}$ and to $8 \mathrm{~mm}$ at $5 \mathrm{mg} / \mathrm{mL}$. At higher concentrations between 10 and $80 \mathrm{mg} / \mathrm{mL}$ of betel leaf crude extract, there were no significant $(P>0.05)$ differences in the size of the inhibition zone. However, at $100 \mathrm{mg} / \mathrm{mL}$, the inhibition zone was $19 \mathrm{~mm}$, significantly $(P<0.05)$ larger than other tested concentrations [Figure 1].

When compared with oxytetracycline, betel leaf crude extract at $100 \mathrm{mg} / \mathrm{mL}$ showed significantly $(P<0.05)$ larger inhibition zone $(19 \mathrm{~mm})$ than the $14 \mathrm{~mm}$ oxytetracycline. However, chloramphenicol resulted in significantly $(P<0.05)$ largest inhibition with $23 \mathrm{~mm}$ [Figure 2].

Turbidity was absent at the concentrations between $0.2 \mathrm{mg} / \mathrm{mL}$ and $50 \mathrm{mg} / \mathrm{mL}$ of betel leaf crude extract. The turbidity first appeared at the concentration of $0.09 \mathrm{mg} / \mathrm{mL}$ of the extract.

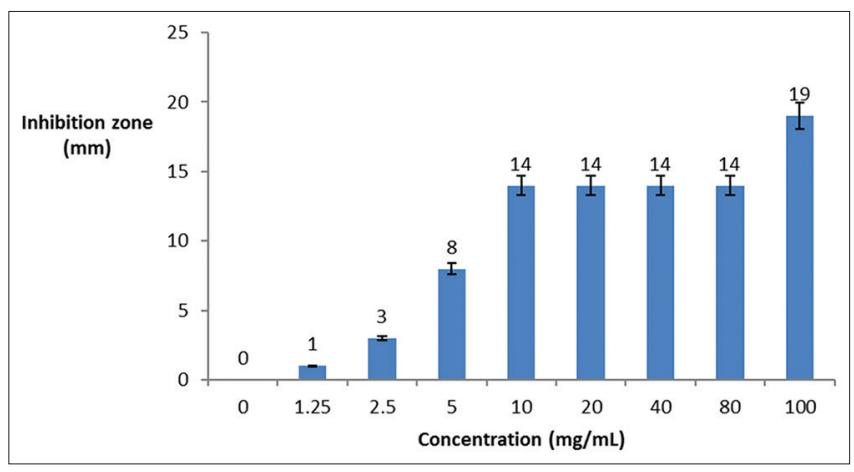

Figure 1: The inhibition zone obtained following disc diffusion method of different concentrations of betel leaf crude extract against Vibrio alginolyticus.

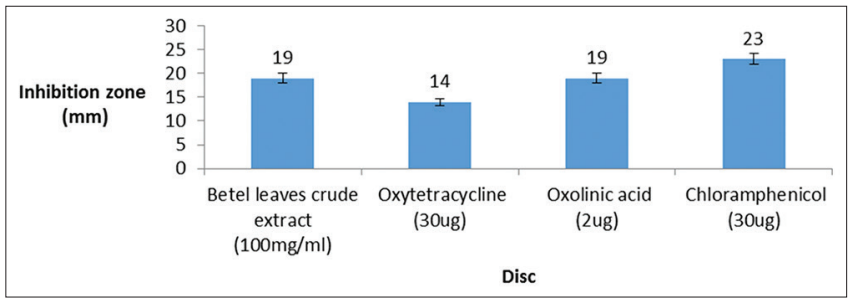

Figure 2: Comparative inhibition zone obtained following disc diffusion method between betel leaf crude extract $(100 \mathrm{mg} / \mathrm{mL})$, oxytetracycline $(30 \mu \mathrm{g})$, oxolinic acid $(2 \mu \mathrm{g})$, and chloramphenicol $(30 \mu \mathrm{g})$ against Vibrio alginolyticus.

Bacterial growth was first detected at the concentration of $0.2 \mathrm{mg} / \mathrm{mL}$ of the extract. Higher concentrations of extract resulted in no bacterial growth.

\section{DISCUSSION}

Humans have used betel leaves for a long period of time as treatment for various diseases and ailments [16]. They contain various phytochemicals including sterol, an active compound that is an excellent antimicrobial [14]. Betel leaves also contain hydroxychavicol, another active compound that possesses powerful antimicrobial effect [13]. Combination of these active compounds resulted in excellent therapeutic effect [17].

Results of this study indicate that the antimicrobial activity of betel leaf crude extract against $V$. alginolyticus is maximum at a high concentration of $100 \mathrm{mg} / \mathrm{mL}$ while intermediate concentrations between 10 and $80 \mathrm{mg} / \mathrm{mL}$ resulted in activity similar to those of commercial antibiotics such as oxytetracycline. Although chloramphenicol showed the strongest antimicrobial activity, it has been banned for use in food animal industry [18]. Similarly, the use of oxolinic acid in aquaculture is harmful to the environment and other aquatic animals as it promotes the antimicrobial-resistant microorganism [19].

The MIC is the lowest concentration of compound that can inhibit bacterial growth while the $\mathrm{MBC}$ is the lowest concentration of the antimicrobial compound that can kill the bacterium. The low MIC and $\mathrm{MBC}$ of betel leaf extract indicate the potential of the extract for use as an alternative to antibiotic in controlling vibriosis in Asian sea bass.

\section{CONCLUSION}

This study revealed the potential use of betel leaf crude extract as antimicrobial agent against marine bacteria. The concentrations between $10 \mathrm{mg} / \mathrm{L}$ and $80 \mathrm{mg} / \mathrm{L}$ are comparable to the commercially 
available antibiotics against $V$. alginolyticus, but the concentration of $100 \mathrm{mg} / \mathrm{L}$ is the best concentration to be recommended.

\section{ACKNOWLEDGMENTS}

The study was partially funded by the Department of Fisheries Malaysia and the HiCOE of the Institute of Bioscience, Universiti Putra Malaysia.

\section{REFERENCES}

1. Mustafa S, Rahman RA. Sustainable marine aquaculture. Recent developments with special reference to Southeast Asia. In: Principles and Potential of Responsible Aquaculture. Borneo Marine Research Institute, University Malaysia Sabah; 2000. p. 3-6.

2. Jerry DA. Biology and Culture of Asian Seabass Lates calcarifer. Danvers, MA: CRC Press; 2013. p. 326.

3. Bert TM. Ecological and Genetic Implications of Aquaculture Activities. The Netherland: Springer; 2007. p. 192.

4. Aoki T. Fish Diseases. United Kingdom: UNESCO/Eolss Publisher; 2016.

5. Manilal A, Sugathan S, Selvin J, Shakir C, Gandhimathi R, Kiran S. Virulence of Vibrios isolated from diseased black tiger shrimp, Penaeus monodon, Fabricius. J World Aqua Soc 2010;41:332-43.

6. Sharma K, Rathore G, Verma D, Sadhu N, Kuriakose P. Vibrio alginolyticus infection in Asian seabass (Lates calcarifer, Bloch) reared in open sea floating cages in India. Aqua Res 2013;44:86-92.

7. Reed PA, Francis-Floyd R. Vibrio infections of fish. EDIS, University of Florida Cooperative Extension Service, Institute of Food and Agriculture Sciences; 1996.

8. Miranda CD, Tello A, Keen PL. Mechanisms of antimicrobial resistance in finfish aquaculture environments. Front Microbiol 2013;4:233.

9. Adwan G, Abu-Shanab B, Adwan K, Abu-Shanab F. Antibacterial effects of nutraceutical plants growing in Palestine on Pseudomonas aeruginosa. Turk J Biol 2006;30:239-42.

10. Chauhan ES, Aishwarya J, Singh A, Tiwari A. A review: Nutraceuticals properties of Piper betel (Paan). Am J Phytomed Clin
Ther 2016;4:28-41.

11. Guha P. Exploring Betel Leaves for Cottage Industry. Kharagpur, India: Agriculture and Food Engineering Department, IIT; 1997. p. 15-9.

12. Pradhan D, Suri KA, Pradhan DK, Biswasroy P. Golden heart of the nature: Piper betle L. J Pharmacog Phytochem 2013;1:147-67.

13. Ali I, Khan FG, Suri KA, Gupta BD, Satti NK, Dutt P, et al. In vitro antifungal activity of hydroxychavicol isolated from Piper betle L. Ann Clin Microbiol Antimicrob 2010;9:7.

14. Chakraborty D, Shah B. Antimicrobial, antioxidative and antihemolytic activity of Piper betel leaf extracts. Int J Pharma Pharm Sci 2011;3:192-9.

15. Palavesam A, Sheeja L, Immanuel G. Antimicrobial properties of medicinal herbal extracts against pathogenic bacteria isolated from the infected grouper Epinephelus tauvina. J Biol Res 2006;6:167-76.

16. Sankaranarayanan S, Bama P, Ramach J, Kalaichelvan PT, Deccaraman M, Vijayalakshimi M, et al. Ethnobotanical study of medicinal plants used by traditional users in Villupuram district of Tamil Nadu, India. J Med Plants Res 2010;4:1089-101.

17. Doughary JH. Phytochemicals: Extraction methods, basic structures and mode of action as potential chemotherapeutic agents. In: Phytochemicals-A global Perspective of their Role in Nutrition and Health. Europe: InTech; 2012.

18. Serrano HP. Responsible use of Antibiotics in Aquaculture. FAO Fisheries Technical Paper. No. 469. Rome: FAO; 2005. p. 97.

19. Guardabassi L, Dalsgaard A, Raffatellu M, Olsen JE. Increase in the prevalence of oxolinic acid resistant Acinetobacter spp. Observed in a stream receiving the effluent from a freshwater trout farm following the treatment with oxolinic acid-medicated feed. Aquaculture 2000;188:205-18.

How to cite this article:

Othman AB, Zamri-Saad M, Nik-Haiha NY, Siti-Zahrah A. In vitro

antimicrobial actitivity of betel, Piper betle leaf extract against Vibrio

alginolyticus isolated from Asian sea bass, Lates calcarifer. J App Biol

Biotech. 2018;6(04):46-48. DOI: 10.7324/JABB.2018.60409 